\title{
Pengaruh Pemberian Ekstrak Daun Beluntas (Pluchea indica L) terhadap Total Kolesterol Darah Broiler
}

\section{Effect of Leaf Extract Pluchea indica L toward Total Blood Cholesterol Broiler}

\section{Yana Sukaryana dan Y. Priabudiman}

Jurusan Peternakan Politeknik Negeri Lampung

Jln. Soekarno Hatta no 10 Rajabasa Bandar Lampung 35145 Telp. 0721703995

\begin{abstract}
The purpose of study was to determine the potential leaf extract Pluchea indica $L$ at broiler in lowering cholesterol, as well as the exact time of administration so that the plant can be used as an alternative to veterinary medicinal plants without any negative effect on productivity. The experimental design used was a complete randomized design (CRD) consisting of 4 treatments with 6 replicates, each occupied by 4 broilers. P1 treatment was leaf extract Pluchea indica L for 3 weeks starting at the age of 1 week, P2 treatment was leaf extract Pluchea indica L for 2 weeks starting at the age of 2 week, P3 treatment was leaf extract Pluchea indica L for 1 weeks starting at the age of 3 week, and P4 treatment without leaf extract Pluchea indica L for maintenance. Examination of the blood cholesterol level was done through a blood sample from the brachial vein any chickens taken at random to represent each repeat unit during 35 day old chicks. Experimental data processed by analysis of variance and if there is a treatment effect followed by Duncan's multiple range test. The results showed that there are significant leaf extract Pluchea indica L to total cholesterol, HDL, and LDL blood broiler. P1 treatment is beluntas leaf extract for 3 weeks starting at the age of 1 week produced a total content of cholesterol (156 $\mathrm{mg} / \mathrm{dl}), \mathrm{HDL}(44 \mathrm{mg} / \mathrm{dl})$, and $\mathrm{LDL}$ $(144 \mathrm{mg} / \mathrm{dl})$ of blood lowest broiler.
\end{abstract}

Keywords : Pluchea indica L, blood cholesterol, broiler.

Diterima 30-01 2014, disetujui: 27-06-2014

\section{PENDAHULUAN}

Laju pertumbuhan penduduk Indonesia yang sejalan dengan pergeseran gaya hidup dan tingkat kesejahteraan masyarakat, menyebabkan semakin meningkatnya kebutuhan akan produk pangan yang berasal dari hewan. Salah satu komoditas peternakan yang sangat mungkin untuk mengimbangi kebutuhan tersebut adalah broiler.

Broiler merupakan salah satu komoditas sektor peternakan yang cukup efisien dalam menyediakan zat-zat makanan sumber protein hewani yang dibutuhkan oleh masyarakat. Selain rasanya yang lezat dan digemari masyarakat, broiler paling mudah didapat dengan harga yang relatif terjangkau berbagai kalangan masyarakat. Potensi broiler yang cukup baik menyebabkan produksi broiler di Provinsi Lampung maupun produksi nasional mengalami peningkatan yang 

Yana Sukaryana dan Y. Priabudiman: Pengaruh Pemberian Ekstrak Daun Beluntas...

cukup pesat. Namun dibalik potensi yang baik tersebut, keberadaan kolesterol yang tinggi pada broiler sering digunakan sebagai pembatas konsumsi broiler dalam masyarakat.

Semakin maju suatu negara, maka semakin pintar masyarakatnya terutama dalam hal memilih pangan yang baik. Tingginya kasus penyakit degeneratif seperti jantung, stroke menjadikan masyarakat harus lebih pintar dalam memilih makanan yang dikonsumsinya. Kandungan kolesterol pada broiler yang tinggi $(200 \mathrm{mg} / \mathrm{dl})$ dibandingkan dengan ayam kampung $(100 \mathrm{mg} / \mathrm{dl}$ ) dapat menjadi faktor pembatas konsumsi terhadap daging broiler (Nikolova and Pavlovski, 2007). Sebagian masyarakat merasa takut untuk mengkonsumsi daging broiler karena dikhawatirkan dapat meningkatkan kadar total kolesterol darah.

Kolesterol merupakan salah satu unsur penting yang diperlukan untuk mengatur berbagai proses kimiawi di dalam tubuh. Namun kolesterol dalam jumlah tinggi bisa menyebabkan terjadinya deposit kolesterol pada dinding pembuluh darah dan menyebabkan kejadian yang disebut sebagai aterosklerosis yang pada akhirnya akan berdampak pada penyakit jantung koroner.

Berkaitan dengan ketakutan sebagian masyarakat terhadap kolesterol, berbagai upaya harus dilakukan untuk menurunkan kadar total kolesterol darah broiler. Banyak cara yang dapat dilakukan untuk menurunkan kadar kolesterol darah ayam diantaranya melalui program genetik, pemberian pakan yang mengandung asam lemak tidak jenuh atau penggunaan obat penurun kolesterol. Cara yang efisien dan efektif yang sangat memungkinkan dilakukan dalam jangka pendek untuk menurunkan kadar kolesterol darah broiler adalah menggunakan obat penurun kolesterol.

Obat alami sudah dikenal dan digunakan di seluruh dunia sejak beribu tahun yang lalu (Padmawinata, 1995). Di Indonesia, penggunaan obat alami yang lebih dikenal sebagai jamu, telah meluas sejak zaman nenek moyang hingga kini dan terus dilestarikan sebagai warisan budaya. Obat alami bukan hanya untuk manusia, tetapi juga dapat digunakan untuk hewan. Penggunaan obat tradisional untuk hewan juga telah lama dilakukan oleh para petani di pedesaan, namun efek farmakologis tanaman obat harus dapat dibuktikan secara empiris melalui kegiatan penelitian.

Tanaman obat yang banyak digunakan pada hewan biasanya hampir sama seperti tanaman yang sering digunakan pada manusia, namun pemilihan tanaman tersebut harus memperhatikan berbagai hal antara lain; penggunaan tanaman tersebut tidak berkompetisi dengan manusia, selain itu murah dan mudah untuk diaplikasikan kepada hewan. Oleh karena itu perlu digali potensipotensi farmakologis dari berbagai tanaman obat sehingga dapat dijadikan alternatif pilihan penggunaannya pada hewan.

Salah satu tanaman yang telah lama dikenal oleh masyarakat Indonesia adalah tanaman beluntas (Pluchea indica L). Tanaman ini sering digunakan sebagai tanaman pagar di halaman rumah penduduk. Masyarakat awam biasanya menggunakan daun beluntas sebagai penurun demam (antipiretik), meningkatkan nafsu makan (stomakik), peluruh keringat (diaforetik), dan penyegar (Dalimartha, 1999). Khasiat yang dimiliki oleh suatu tanaman dihasilkan dari kandungan bahan aktif yang dimiliki oleh tanaman tersebut. Menurut Asimayu (2003), daun beluntas mengandung alkaloid, tannin, natrium, minyak atsiri, kalsium, flavonoid, magnesium, fosfor, asam amino (leusin, triptofan, treonin), vitamin A dan C. Berdasarkan kandungan bahan aktif yang dimiliki oleh daun beluntas, masih banyak potensi farmakologis daun beluntas yang belum banyak diketahui salah satunya adalah sebagai penurun kolesterol. Pada beberapa tanaman, fungsi penurun kolesterol disebabkan karena kandungan flavonoid dari tanaman tersebut.

Kandungan tannin pada tanaman dapat menyebabkan gangguan pencernaan yang akan mempengaruhi pertumbuhan hewan yang mengkonsumsinya. Kandungan bahan bahan aktif pada 
Jurnal Penelitian Pertanian Terapan

daun beluntas yang bekerja tidak selalu sinergis dalam meningkatkan kualitas broiler, menyebabkan perlunya dilakukan penelitian untuk mengetahui potensi daun beluntas dalam menurunkan kolesterol broiler, serta waktu pemberiannya yang tepat sehingga tanaman ini dapat dijadikan alternatif lain tanaman obat pada hewan tanpa berpengruh negatif pada produktivitasnya.

\section{METODE}

Penelitian dilakukan di Kandang Peternakan dan di Laboratorium ternak, Politeknik Negeri Lampung. Bandar Lampung. Penelitian berlangsung selama 4 bulan dari bulan September sampai Desember 2013.Bahan dan alat yang digunakan pada penelitian ini adalah: Daun beluntas, Day Old Chick (DOC) broiler (CP 707). Spoid, Kapas, Alkohol, Pippetor, Sentrifus, Microtube, dan Venoject.

Dalam mempelajari pengaruh pemberian ekstrak daun beluntas terhadap kadar kolesterol darah broiler, dilakukan percobaan dengan menggunakan 96 ekor ayam yang dibagi menjadi 4 kelompok perlakuan (Tabel 1).

Tabel 1. Umur dan lama pemberian ekstrak daun beluntas

\begin{tabular}{ccc}
\hline Perlakuan & Umur Pemberian (minggu) & $\begin{array}{c}\text { Lama Pemberian } \\
(\text { minggu) }\end{array}$ \\
\hline P1 & 1 & 3 \\
P2 & 2 & 2 \\
P3 & 3 & 1 \\
P4 & Tanpa pemberian & 0 \\
\hline
\end{tabular}

Setiap kelompok ayam diletakkan dalam kandang terpisah dengan tingkat densitas yang sama. Rancangan percobaan yang digunakan adalah Rancangan Acak lengkap (RAL) yang terdiri dari 4 perlakuan dengan 6 ulangan, masing-masing ulangan ditempati oleh 4 ekor broiler. Pemeriksaan kadar kolesterol darah dilakukan melalui pengambilan darah vena brachialis dari setiap ekor ayam yang diambil secara acak untuk mewakili setiap unit ulangan pada saat ayam berumur 35 hari. Selanjutnya, data percobaan diolah dengan analisis ragam berdasarkan rancangan acak lengkap menggunakan program SPSS for windows Version 12 yang dilanjutkan dengan uji jarak berganda Duncan (Steel and Torrie, 2009).

Pelaksanaan penelitian dimulai dari penyiapan ekstrak daun beluntas. Ekstrak daun beluntas dibuat dari daun beluntas segar yang telah dicuci dan ditiriskan. Setelah itu daun beluntas ditimbang dan dihaluskan menggunakan blender dengan ditambahkan air suhu $70-80^{\circ} \mathrm{C}$, dengan perbandingan $1: 2(\mathrm{~b} / \mathrm{v})$. Ekstrak yang dihasilkan disaring dengan kain kasa untuk selanjutnya diberikan pada broiler dengan tingkat pemberian $10 \%$.

Penelitian ini menggunakan 96 ekor broiler strain CP-707 yang diperoleh secara komersial dari perusahaan penetasan ayam di daerah Bandar Lampung. Ayam umur 1-3 hari ayam dipelihara dalam satu kandang indukan. Setelah umur 4 hari ayam-ayam tersebut dibagi menjadi 4 kelompok secara acak. Selama penelitian ayam diberi pakan komersial dan air minum secara ad libitum.

Penyiapan sampel serum yaitu pengambilan darah pada ayam melalui vena brachialis sebanyak 0,5-1 ml untuk setiap sampel. Pengambilan darah dilakukan pada saat setelah selesai penimbangan berat badan terakhir. Darah kemudian dibiarkan dalam posisi miring dalam tabung 
Yana Sukaryana dan Y. Priabudiman: Pengaruh Pemberian Ekstrak Daun Beluntas...

selama 30 menit pada suhu kamar, dan selanjutnya disimpan dalan refrigerator selama 24 jam sampai serum terpisah dari benda darah.

Pengamatan dilakukan dengan cara pengambilan sampel darah, dilakukan pada saat panen (ayam berumur 35 hari). Hasil darah yang diperoleh di buat serum dan dianalisis kandungan total kolesterol darahnya dengan metode Liebermann-Buchard.

\section{HASIL DAN PEMBAHASAN}

Tabel 2. Rata-rata Hasil Analisis Kandungan Total Kolesterol Darah broiler

\begin{tabular}{ccccc}
\hline \multirow{2}{*}{ Analisis } & \multicolumn{4}{c}{ Perlakuan } \\
\cline { 2 - 4 } & $\mathrm{P} 1$ & $\mathrm{P} 2$ & $\mathrm{P} 3$ & $\mathrm{P} 4$ \\
\hline Kolesterol & $156^{\mathrm{a}}$ & $177^{\mathrm{b}}$ & $220^{\mathrm{c}}$ & $289^{\mathrm{d}}$ \\
HDL & $42^{\mathrm{a}}$ & $55^{\mathrm{b}}$ & $63^{\mathrm{c}}$ & $66^{\mathrm{c}}$ \\
LDL & $114^{\mathrm{a}}$ & $119^{\mathrm{a}}$ & $146^{\mathrm{b}}$ & $183^{\mathrm{c}}$ \\
\hline
\end{tabular}

Keterangan: Superskrip yang tidak sama pada baris menunjukkan berbeda nyata $(\mathrm{P}<0,05)$

Pada Tabel 2 dapat dilihat rata-rata hasil analisis kandungan total kolesterol darah broiler terendah pada perlakuan P1 yaitu sebesar $156 \mathrm{mg} / \mathrm{dl}$, sedangkan rata-rata hasil analisis kandungan total kolesterol darah broiler tertinggi pada perlakuan P4 yaitu sebesar $289 \mathrm{mg} / \mathrm{dl}$. Hasil analisis ragam menunjukkan perbedaan nyata antara perlakuan P1, P2, P3, dan P4. Yusniar dan Nilasari (2004) menyatakan, ayam broiler yang diberi pakan komersial rata-rata menghasilkan kandungan kolesterol darah lebih dari $200 \mathrm{mg} / \mathrm{dl}$. Hasil penelitian ini menunjukkan bahwa terjadi pengaruh pemberian ekstrak daun beluntas (Pluchea indica L) terhadap total kolesterol darah broiler. Perlakuan P1 yaitu pemberian ekstrak daun beluntas selama 3 minggu yang dimulai pada umur 1 minggu menghasilkan kandungan total kolesterol darah broiler terendah dan ini menunjukkan ada indikasi telah terjadi penurunan kandungan total kolesterol darah atau dengan kata lain pemberian ekstrak daun beluntas mampu menurunkan kolesterol dalam darah broiler. Pada perlakuan P1 diduga fungsi hati sebagai tempat utama untuk pencernaan dan penyerapan lemak melalui produksi getah empedu yang mengandung kolesterol serta garam-garam empedu yang disintesis dalam hati berjalan dengan baik. Peningkatan jumlah kolesterol dan ketidak seimbangan di dalam lipoprotein akan menyebabkan beberapa masalah dan dapat menyebabkan resiko penyakit jantung.

Secara tradisional daun beluntas berkhasiat untuk meningkatkan nafsu makan, membantu melancarkan pencernaan, meluruhkan keringat, menghilangkan bau badan dan bau mulut, meredakan demam, nyeri tulang, sakit pinggang, dan keputihan. Daun beluntas mengandung alkaloid, tannin, natrium, minyak atsiri, kalsium, flavonoid, magnesium, fosfor, asam amino (leusin, triptofan, treonin), vitamin A dan C (Asiamaya, 2003). Kandungan flavonoida dan saponin pada tanaman dapat dimanfaatkan untuk menurunkan koleterol. Penggunaan ekstrak daun beluntas pada broiler telah dilaporkan oleh Setiaji (2005), bahwa ekstrak daun beluntas dapat digunakan sampai level 10\% pada air minum sebagai antistres yang diberikan secara diskontinyu.

Rata-rata hasil analisis kandungan HDL darah broiler terendah pada perlakuan P1 yaitu sebesar $42 \mathrm{mg} / \mathrm{dl}$, sedangkan rata-rata hasil analisis kandungan HDL darah broiler tertinggi pada perlakuan P4 yaitu sebesar $66 \mathrm{mg} / \mathrm{dl}$ (Tabel 2). Hasil analisis ragam menunjukkan perbedaan nyata antara perlakuan P1 dengan, P2, P3, dan P4. Perbedaan nyata antara perlakuan P2 dengan P3 dan 
P4, sedangkan antara P3 dan P4 tidak berbeda nyata. HDL diperlukan dalam sintesis senyawa steroid seperti hormon atau garam empedu di hati. Sesuai dengan pendapat Murray et al. (2003) yang menyatakan bahwa penurunan HDL dapat disebabkan oleh : aliran masuknya kolesterol dari lipoprotein yang potensial kolesterolnya rendah (HDL) menuju membran sel, dan penggunaan HDL untuk sintesis senyawa steroid seperti hormon atau garam empedu di hati. HDL dipengaruhi oleh pakan, gen, lingkungan dan keadaan ternak. Semakin nyaman ayam broiler maka kolesterol akan diangkut kembali oleh HDL untuk dibawa kembali ke hati yang selanjutnya akan diuraikan lalu dibuang ke dalam kandung empedu sebagai asam (cairan) empedu (Yusniar dan Nilasari, 2009).

Rata-rata hasil analisis kandungan LDL darah broiler terendah pada perlakuan P1 yaitu sebesar $144 \mathrm{mg} / \mathrm{dl}$, sedangkan rata-rata hasil analisis kandungan LDL broiler tertinggi pada perlakuan P4 yaitu sebesar $183 \mathrm{mg} / \mathrm{dl}$ (Tabel 2). Nilai tersebut terbilang lebih tinggi bila dibandingkan dengan pendapat Miruka dalam Manoppo et al. (2007) bahwa kadar LDL ayam yang normal sebesar 95-125 mg/dl. Sintesis LDL banyak dipengaruhi oleh faktor pakan, lingkungan dan genetik ayam (Yusniar dan Nilasari, 2009). Hasil analisis ragam menunjukkan perlakua P1 dan P2 tidak berbeda nyata, sedangkan dengan perlakuan P3 dan P4 berbeda nyata. Demikian pula antara perlakuan P3 dengan P4 berbeda nyata. Jenis kolesterol LDL dianggap sebagai kolesterol jahat, sementara HDL dianggap sebagai kolesterol baik.

\section{KESIMPULAN}

Berdasarkan hasil penelitian dapat disimpulkan bahwa terdapat pengaruh pemberian ekstrak daun beluntas (Pluchea indica L) terhadap total kolesterol, HDL, dan LDL darah broiler. Perlakuan P1 adalah pemberian ekstrak daun beluntas selama 3 minggu yang dimulai pada umur 1 minggu menghasilkan kandungan total kolesterol (156 ml/dl), HDL (44 mg/dl), dan LDL (144 $\mathrm{ml} / \mathrm{dl}$ ) darah broiler terendah.

\section{DAFTAR PUSTAKA}

Almatsier, S. 2005. Prinsip Dasar Ilmu Gizi. PT Gramedia Pustaka Utama. Jakarta.

Asiamaya. 2003. Beluntas. http://www.asiamaya.com/jamu/isi/beluntas_pluchea indica less (12 Maret 2006).

Dalimartha, S. 1999. Atlas Tumbuhan Obat Indonesia. Trubus Agriwidya. Jakarta.

FAO/OIE/WHO. 2006. Report of Workshops Antimicrobial Use in Aquaculture and Antibiotic resistance. Seoul. Republic of Korea.

Hammer, K.A., C.F. Carson,dan T.V. Riley. 1999. Antimicrobial Activity Of Essential Oils And Other Plant Extracts. J. Appl. Microbiol. 86: 985-990.

Harjosworo, P.S. dan Rukmiasih, M.S. 2000. Meningkatkan Produksi Daging Unggas. Penebar Swadaya. Yogyakarta.

Kurniadi, A. 1992. Jenis Penyakit Domba serta Cara Pengendaliannya. Sinar Tani. 
Yana Sukaryana dan Y. Priabudiman: Pengaruh Pemberian Ekstrak Daun Beluntas...

Koolman, J., and K.H. Rohm. 2001. Color Atlas of Biochemistry. Stuttgart, Germany

Manoppo, M. R. A., R. Sugihartuti, T. S. Adikara dan Y. Dhamayanti. 2007. Pengaruh Pemberian Crude Chrorella terhadap Total Kolesterol Darah Ayam Broiler. Fakultas Kedokteran Hewan. Universitas Airlangga.

Mardisiswojo, Sudarman, dan H. Rajakmangunsudarso. 1995. Cabe Puyang warisan Nenek Moyang. Balai Pustaka.

Murray, R. K., D. K. Granner, P. A. Mayes dan V. W. Rodwell. 2003. Biokimia Harper. Penerbit Buku Kedokteran ECG Jakarta. (Diterjemahkan oleh A. Hartono).

Nikolova, R. and Z. N. Pavlovski, 2007. The quantity of abdominal fat in broiler of different genotype from 5 to 7 weeks age. Bioteknology of Animal Husbandry. http://www.istocar.bg.ac.yu/radovi2/38.pdf. Diakses 22 Nov 2009

Padmawinata, K 1995. Potensi, Peluang dan Kendala Pengembangan Agroindustri Tanaman Obat. BALITRO.

Putri, D.D., R. Noviadi, dan Nurhayati. 2008. Efek Pemberian Teh Kelopak Buah Rosela (Hibiscus sabdariffa) untuk Meningkatkan Respon Imunologis Ayam Ras Pedaging. Laporan Penelitian.

Rasyaf, M. 2010. Beternak Ayam Pedaging. Penebar Swadaya. Jakarta.

Sarwono, B. 2002. Jamu Untuk Ternak. Penebar Swadaya

Setiaji, D., dan A. Sudarman. 2005. Ekstrak Daun Beluntas (Pluchea indiica L) sebagai obat anti stres pada ayam broiler. Jurnal Media Peternakan pp 46-51.

Setyadi F, V. D. Y. B. Ismadi, dan I. Mangisah. 2013. Blood Cholesterol, HDL and HDL Level Due to Combination of Lighting Period and Feed Serving on Broiler. Animal Agriculture Journal, Vol. 2(1):68 - 76 .

Soedarmo, P., dan Soedioetama. 1887. Ilmu Gizi. Penerbit Dian Rakyat. Jakarta. Dikutip dari penelitian Suhendra Pantjawidjaja. Jurusan Nutrisi dan Makanan Ternak Fakultas Peternakan Universitas Hasanudin. Makasar.

Yusniar, L. dan E. Nilasari. 2009. Biar Daging Ayam Tidak Berkolesterol Tinggi. http://www.majalahtrust.com/biar.daging.ayam.tidak.berkolesterol.tinggi/284.php (22 Juli 2012). 